\title{
The EBMT: History, Present, and Future
}

\author{
Alois Gratwohl, Mohamad Mohty, \\ and Jane Apperley
}

\subsection{Introduction}

"Only he/she who knows the past has a future" is a proverb attributed to Wilhelm von Humboldt (1767-1835), a great historian, scientist, and philosopher (Spier 2015). It appears as an ideal introduction to a chapter on the history of EBMT. The context by which HSCT evolved in the middle of last century fits with modern views on history. The novel "big history" concept attempts to integrate major events in the past, beginning with the "big bang" up to today's industrial revolution number IV (Spier 2015). According to this model, nothing "just happens." Progress occurs when the conditions fit, at the right time and at the right place. Such circumstances are called "Goldilocks conditions," according to the novel by Robert Southey (https:// en.wikipedia.org/wiki/Goldilocks_and_the_ Three_Bears. accessed November 6, 2018). They hold true for the formation of galaxies, suns, and planets, for the appearance of life on earth, or for

A. Gratwohl $(\bowtie)$

Hematology, Medical Faculty, University of Basel,

Basel, Switzerland

e-mail: alois.gratwohl@unibas.ch

M. Mohty

Hematology, Hôpital St. Antoine, Sorbonne

University, Paris, France

J. Apperley

Centre for Haematology, Hammersmith Hospital, Imperial College London, London, UK the evolution of mankind. They apply specifically to the latter: as the one and only species, Homo sapiens managed to create "Goldilocks conditions" by him or herself. They allowed man to fit religion, art, or beliefs in such ways to master society. In our perspective, big history thinking helps to understand the development of HSCT and EBMT and to view it in a broader framework. It provides as well a caveat for the future.

\subsection{The Past: Development of HSCT and EBMT}

The use of bone marrow (BM) for healing purposes dates back long in history, and BM from hunted animals might have contributed as rich nourishment to the evolution of Homo sapiens (McCann 2016). Its recognition as primary hematopoietic organ in adult life with a hematopoietic stem cell as source of the circulating blood cells began in the middle of the nineteenth century (Schinck 1920). It did result in some early recommendations on the potential therapeutic use of bone marrow (JAMA 1997; Osgood et al. 1939), but with no broader application. All changed after the explosions of atomic bombs in Hiroshima and Nagasaki in World War II, when survivors of the immediate exposure died from BM failure (Van Bekkum and De Vries 1967). Research was directed to find ways to treat this lethal complication. It led to the discovery that bone marrow-derived stem cells 
from a healthy donor could replace hematopoiesis after total body irradiation (TBI); it provided at the same time, a tool, TBI, to eradicate aberrant hematopoiesis (Van Bekkum and De Vries 1967; Jacobson et al. 1949; Lorenz et al. 1951; Ford et al. 1956). The concept of HSCT was born, and "the conditions were right." It is to no surprise that the first clinical BMT centers in Europe started in hospitals with close links to radiobiology research institutes in the UK, the Netherlands, France, and Germany. Funding of radiobiology fostered basic research and stimulated clinical application. In the first series of patients reported in the NEJM in 1957 by the late Nobel Prize winner ED Thomas, all six patients died but two of them with clear signs of donor chimerism (Thomas et al. 1957). And, BMT "saved" accidentally irradiated workers of a radiation facility in Vinca, a town in former Jugoslawia (Mathé et al. 1959). Hence, the clinical results confirmed the "proof of principle" obtained in mice: TBI could eradicate normal and malignant bone marrow cells, and the infusion of healthy donor bone marrow cells could restore the recipient's depleted hematopoiesis with functioning donor cells. In reality, of more than 200 patients reported by M. Bortin for the IBMTR, all patients with leukemia had died, many of them free of their disease. Three patients survived, all with congenital immune deficiency and transplanted from HLA-identical sibling donors (Bortin 1970). Despite the dismal results, Goldilocks conditions prevailed. Armed forces were convinced of the need for a rescue tool in the event of a nuclear war, physicians viewed BMT as an instrument to treat hitherto incurable blood disorders, and patients envisioned a cure of their lethal disease.

In order to improve outcome, the "believers" joined forces. They met each other, openly reviewed their cases and charts one by one, exchanged views on hurdles and opportunities, spent time together on the slopes in the Alps, and became friendly rivals: EBMT was born. Goldilocks conditions still prevailed. Leukemia could be eradicated. BMT with haploidentical donor bone marrow for SAA after conditioning with ATG yielded spectacular results (Speck et al. 1977). Today, we know that ATG, rather than the cells, was responsible for the outcome.
The introduction of intensive induction regimens for AML enabled stable phases of complete first remission (CR1) (Crowther et al. 1970). The discovery of CSA, as the first of its kind of novel IS agents, opened new dimensions in BMT and other organ transplantation (Kay et al. 1980). It became acceptable to transplant patients in early phase of their disease, e.g., CR1 or first chronic phase (CP1) (Thomas et al. 1975). The boom of BMT began (Thomas 2007; Gratwohl et al. 2015a). The first patient in the EBMT database dates back to 1965. In 1973, at the first informal gathering in St. Moritz, the database comprised 13 patients; 4 transplanted in that year. In 1980, a total of 285 HSCT were performed, increasing to 402510 years later.

HSCT rapidly diversified in terms of donor type, by including autologous and allogeneic stem cells from related and unrelated donors, and of stem cell source, from bone marrow and peripheral blood to cord blood. Indications expanded from the early congenital immunodeficiency, leukemia, and aplastic anemia to a full variety of severe congenital disorders of the hematopoietic system, to other hematological malignancies such as myeloma and lymphoma, and to non-hematological malignancies, e.g., germ cell tumors. The HSCT technology improved to encompass a variety of in vivo and ex vivo GvHD prevention methods and conditioning regimens of varying intensities with or without TBI. HSCT became open to centers with no links to radiobiology institutes and was no longer bound to "sterile units" and to selected countries (Gratwohl et al. 2015a; Copelan, 2006).

The previously informal gatherings and the database no longer sufficed to share the urgently needed information exchange. EBMT became a formal structure, with elections for presidents and working party chairs. It was listed in PubMed for the first time in 1985 (EBMT 1985). The meetings were no longer confined to ski resorts and became open to all involved in patient care and scientific analyses (Table 2.1). Obviously, organization of the annual meeting is today a major undertaking and only possible with the support of corporate sponsors. Still, the initial spirit remains. 
Table 2.1 List of EBMT meetings and presidents

\begin{tabular}{|c|c|c|c|}
\hline Year & Location annual meeting & Participating groups & EBMT president \\
\hline 1974 & & & Informal gathering \\
\hline 1975 & St. Moritz, Switzerland & 1st P & \\
\hline 1976 & St. Moritz, Switzerland & 2nd $\mathrm{P}$ & B. Speck ${ }^{a}$ \\
\hline 1977 & Courchevel, France & 3rd P & B. Speck ${ }^{a}$ \\
\hline 1978 & Courchevel, France & 4th P & B. Speck ${ }^{a}$ \\
\hline 1979 & St. Moritz, Switzerland & 5th P & E. Gluckman \\
\hline 1980 & Sils-Maria, Switzerland & 6th P & E. Gluckman \\
\hline 1981 & Courchevel, France & 7th P & E. Kubanek \\
\hline 1982 & Courmayeur, Italy & 8th P & E. Gordon-Smith \\
\hline 1983 & Oberstdorf, Germany & 9th P & E. Gordon-Smith \\
\hline 1984 & Granada, Spain & 10th P & J. Barrett \\
\hline 1985 & Bad Hofgastein, Austria & 11th P, 1st N & J. Barrett \\
\hline 1986 & Courmayeur, Italy & 12th P, 2nd N & A. Marmont ${ }^{\mathrm{a}}$ \\
\hline 1987 & Interlaken, Switzerland & 13th P, 3rd N & A. Marmont ${ }^{\mathrm{a}}$ \\
\hline 1988 & Chamonix, France & 14th P, 4th N & G. Gharton \\
\hline 1989 & Bad Hofgastein, Austria & 15th $\mathrm{P}, 5$ th $\mathrm{N}$ & G. Gharton \\
\hline 1990 & The Hague, Netherlands & 16th P, 6th N & J. Goldman ${ }^{\mathrm{a}}$ \\
\hline 1991 & Cortina d'Ampezzo, Italy & 17th P, 7th N & J. Goldman ${ }^{\mathrm{a}}$ \\
\hline 1992 & Stockholm, Sweden & 18th P, 8th N & J. Goldman ${ }^{\mathrm{a}}$ \\
\hline 1993 & $\begin{array}{l}\text { Garmisch-Partenkirchen, } \\
\text { Germany }\end{array}$ & 19th P, 9th N & J. Goldman ${ }^{\mathrm{a}}$ \\
\hline 1994 & Harrogate, UK & 20th P, 10th N & A. Gratwohl \\
\hline 1995 & Davos, Switzerland & 21st $\mathrm{P}, 11$ th $\mathrm{N}$ & A. Gratwohl \\
\hline 1996 & Vienna, Austria & 22nd $\mathrm{P}, 12$ th $\mathrm{N}$ & A. Gratwohl \\
\hline 1997 & Aix-les-bains, France & 23rd P, 13th N & A. Gratwohl \\
\hline 1998 & Courmayeur, Italy & 24th P, 14th N & A. Bacigalupo \\
\hline 1999 & Hamburg, Germany & 25th $\mathrm{P}, 15$ th $\mathrm{N}$ & A. Bacigalupo \\
\hline 2000 & Innsbruck, Germany & 26th P, 16th N & A. Bacigalupo \\
\hline 2001 & Maastricht, Netherlands & 27th P, 17th N & A. Bacigalupo \\
\hline 2002 & Montreux, Switzerland & 28th P, 18th N, 1st DM & J. Apperley \\
\hline 2003 & Istanbul, Turkey & 29th P, 19th N, 2nd DM & J. Apperley \\
\hline 2004 & Barcelona, Spain & 30th P, 20th N, 3d DM & J. Apperley \\
\hline 2005 & Prague, Czech Republic & 31st P, 21st N, 4th DM & J. Apperley \\
\hline 2006 & Hamburg, Germany & 32nd P, 22nd N, 5th DM & D. Niederwieser \\
\hline 2007 & Lyon, France & 33rd P, 23d N, 6th DM, 1st P\&F & D. Niederwieser \\
\hline 2008 & Florence, Italy & 34th P, 24th N, 7th DM, 2nd P\&F & D. Niederwieser \\
\hline 2009 & Goteborg, Sweden & 35th P, 25th N, 8th DM, 3rd P\&F & D. Niederwieser \\
\hline 2010 & Vienna, Austria & 36th P, 26th N, 9th DM, 4th P\&F & A. Madrigal \\
\hline 2011 & Paris, France & 37th $\mathrm{P}, 27$ th $\mathrm{N}, 10$ th $\mathrm{DM}, 5$ th $\mathrm{P} \& \mathrm{~F}$ & A. Madrigal \\
\hline 2012 & Geneva, Switzerland & 38th P, 28th N, 11th DM, 6th P\&F, 1st QM, 1st Ped & A. Madrigal \\
\hline 2013 & London, UK & 39th P, 29th N, 12th DM, 7th P\&F, 2nd QM, 2nd Ped & A. Madrigal \\
\hline 2014 & Milan, Italy & 40th P, 30th N, 13th DM, 8th P\&F, 3d QM, 3d Ped & A. Madrigal \\
\hline 2015 & Istanbul, Turkey & 41st P, 31st N, 14th DM, 9th P\&F, 4th QM, 4th Ped & M. Mohty \\
\hline 2016 & Valencia, Spain & $\begin{array}{l}\text { 42nd P, 32nd N, 15th DM, 10th P\&F, 5th QM, } \\
\text { 5thPed, 1stPha }\end{array}$ & M. Mohty \\
\hline 2017 & Marseille, France & $\begin{array}{l}\text { 43rd P, 33rd N, 16th DM, 11th P\&F, 6th QM, } \\
\text { 6thPed, 2nd Pha }\end{array}$ & M. Mohty \\
\hline 2018 & Lisbon, Portugal & $\begin{array}{l}\text { 44th P, 34th N, 17th DM, 12th P\&F, 7th QM, } \\
\text { 7thPed, 3d Pha }\end{array}$ & M. Mohty \\
\hline 2019 & Frankfurt, Germany & $\begin{array}{l}\text { 45th P, 35th N, 18th DM, 13th P\&F, 8th QM, 8th } \\
\text { Ped, 4th Pha }\end{array}$ & N. Kröger \\
\hline
\end{tabular}

Participating groups: $P$ physicians, $N$ nurses, $D M$ data manager, $P \& F$ patient and family day, $Q M$ quality manager, Ped pediatricians, Pha pharmacists ${ }^{\text {adeceased }}$ 


\subsection{The Present}

Today, EBMT (www.ebmt.org) is a nonprofit organization with a clear mission statement: "To save the lives of patients with blood cancers and other lifethreatening diseases by advancing the fields of blood and marrow transplantation and cell therapy worldwide through science, education and advocacy" (https://portal.ebmt.org/Contents/About-EBMT/ Mission-Vision/Pages/Mission\%2D\%2DVision. aspx. Accessed 26 Feb 2018). It is formally a professional society with legal residence in the Netherlands and an administrative office in Barcelona, Spain. EBMT is chaired by the president, who is elected by the members for 2 years and for a maximum of two terms. He/she is supported by the board of association as the executive committee and the board of counselors as external advisors. The scientific council which represents the 11 working parties, the seven committees, and the groups guides the scientific work with the help of the seven offices (Table 2.2). The main task of the organizational body of EBMT is to collect, analyze, and disseminate scientific data; to conduct clinical trials; to improve quality through the close cooperation with JACIE and FACT; to plan the annual meeting, the educational events, and training courses, including the EBMT Handbook; and to provide assistance to patients, donors, physicians, and competent authorities.

Members of the EBMT are mainly centers active in transplantation of hematopoietic stem cells (HSC) or any other organization involved in the care of donors and recipients of HSC. Currently (January 1, 2018), EBMT holds 509 full center members and 55 associate center members, 122 individual, and 35 honorary members, from 65 different countries. EBMT is supported in its activities through the membership fees and the revenue of the annual meetings and by its corporate sponsors (https://www2.ebmt. org/Contents/Members-Sponsors/Sponsors/ Listofcorporatesponsors/Pages/List-ofcorporate-sponsors.aspx. Accessed 26 Feb 2018). EBMT is part of the global network of organizations involved in HSCT, the Worldwide Network for Blood and Marrow Transplantation (WBMT), and in close link with national and other
Table 2.2 EBMT working parties, committees, groups and offices

\begin{tabular}{|c|c|}
\hline \multicolumn{2}{|c|}{ Working parties } \\
\hline ADWP & Autoimmune Diseases Working Party \\
\hline ALWP & Acute Leukemia Working Party \\
\hline CMWP & Chronic Malignancies Working Party \\
\hline CTIWP & $\begin{array}{l}\text { Cellular Therapy \& Immunobiology Working } \\
\text { Party }\end{array}$ \\
\hline IDWP & Infectious Diseases Working Party \\
\hline IEWP & Inborn Errors Working Party \\
\hline LWP & Lymphoma Working Party \\
\hline PDWP & Paediatric Diseases Working Party \\
\hline SAAWP & Severe Aplastic Anaemia Working Party \\
\hline STWP & Solid Tumors Working Party \\
\hline TCWP & Transplant Complications Working Party \\
\hline \multicolumn{2}{|c|}{ Committees } \\
\hline & Nuclear Accident Committee \\
\hline & Donor Outcomes Committee \\
\hline & Statistical Committee \\
\hline & Registry Committee \\
\hline & JACIE Committee \\
\hline & Global Committee \\
\hline & Legal \& Regulatory Affairs Committee \\
\hline \multicolumn{2}{|l|}{ Groups } \\
\hline & EBMT nurses' group with its own president \\
\hline & Data managers' group \\
\hline & Statisticians' group \\
\hline \multicolumn{2}{|c|}{ EBMT units } \\
\hline & EBMT Executive Office, Barcelona, Spain \\
\hline & $\begin{array}{l}\text { JACIE Accreditation Office, Barcelona, } \\
\text { Spain }\end{array}$ \\
\hline & EBMT Central Registry Office, London, UK \\
\hline & EBMT Data Office, Leiden, The Netherlands \\
\hline & $\begin{array}{l}\text { EBMT Clinical Trials Office, Leiden, The } \\
\text { Netherlands }\end{array}$ \\
\hline & $\begin{array}{l}\text { EBMT Data Office/CEREST-TC, Paris, } \\
\text { France }\end{array}$ \\
\hline & $\begin{array}{l}\text { EBMT Activity Survey Office, Basel, } \\
\text { Switzerland }\end{array}$ \\
\hline
\end{tabular}

Courtesy: EBMT office Barcelona, Marta Herrero Hoces

international professional organizations involved in HSCT, such as AFBMT, APBMT, CIBMTR, EMBMT, LABMT, or WMDA. The EBMT database now holds information on more than 500,000 transplants. Over 35,000 new patients were treated annually over the last 5 years and more than 40,000 HSCT performed (Fig. 2.1). An estimated number of more than 400,000 patients are currently alive after HSCT in Europe; they reflect the EBMT achievements and the challenges ahead. 


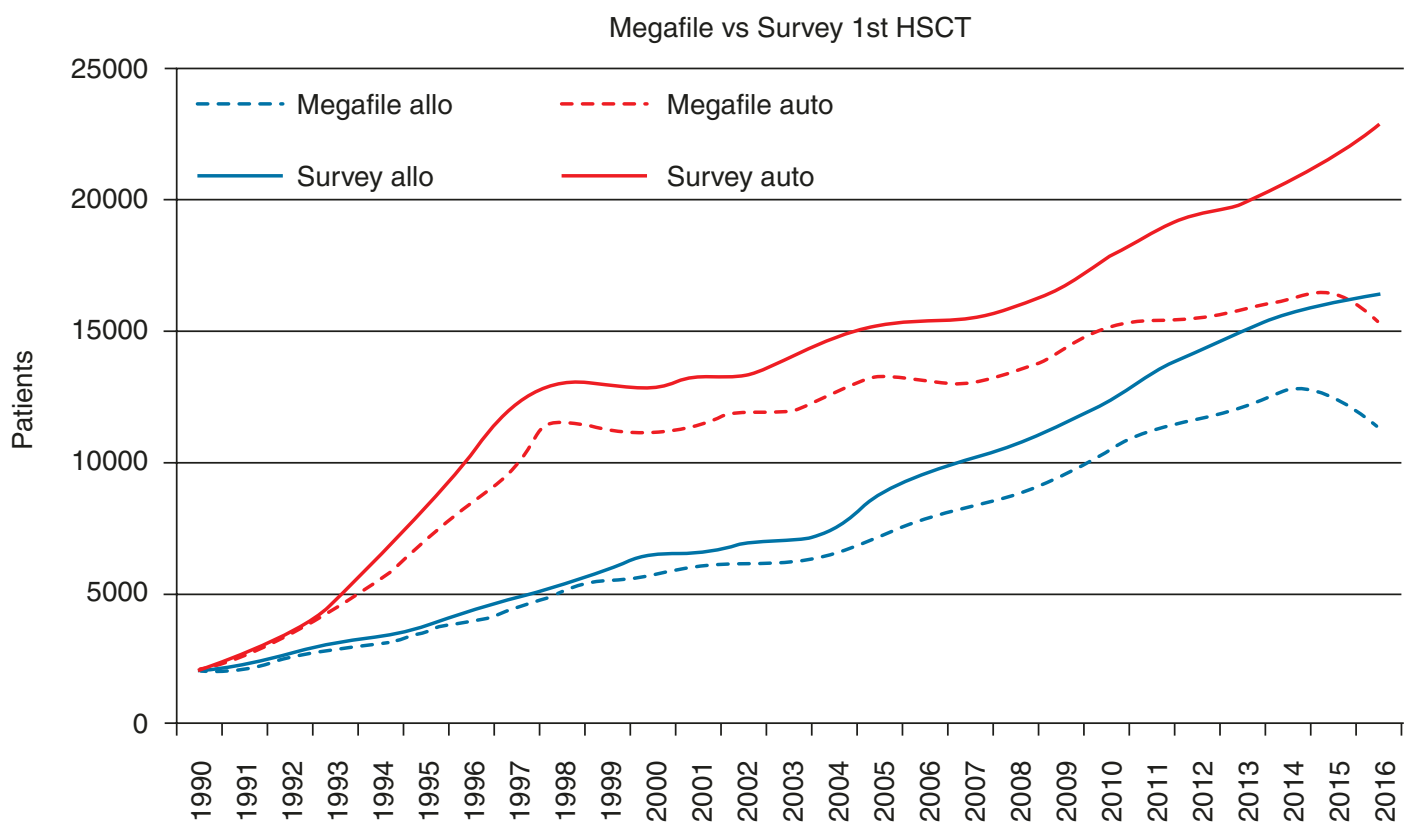

Fig. 2.1 Numbers of patients with a first HSCT by main donor type and year of transplant. The lines reflect the difference in patient numbers with and without information

\section{$2.4 \quad$ The Future}

Again, according to the Big History concept, predicting the future is a difficult task: "There are no data about the future; from an empirical scientific point of view, it is impossible to say what lies ahead of us." (Spier 2015). But we can project scenarios; we know the past, and we see the today. We live in the rapidly evolving world of the industrial revolution IV, dominated by globalization, digitization, and personalized medicine. Targeted therapies promise cures; gene-modified cells destroy hitherto untreatable cancers; immunomodulation with checkpoint inhibitors has become a reality (Hochhaus et al. 2017; Tran et al. 2017; Le et al. 2015). If HSCT is to remain a valuable treatment, mentalities and methods of the past no longer suffice. The idea of beliefs, hence physicians creating their own Goldilocks conditions, will lead to the end of HSCT. It has to be replaced by a stringent scientific approach. The sad story of HSCT for breast cancer, with more than 40,000 transplants but no clear answer, must not to be repeated (Gratwohl et al. 2010). in the database (megafile). Courtesy: Carmen Ruiz de Elvira, EBMT megafile office, London; Helen Baldomero, EBMT activity survey office, Basel

Hence, prediction number one: The idea of "a donor for everybody" will be abandoned. HSCT has to provide for the individual patient the best outcome regarding overall survival, quality of life and costs. The outcome after HSCT must be superior, in these three aspects, to any of the modern drugs or treatments, including "watch and wait" strategies or palliation. Assessment of risks needs to integrate risk factors relating to the patient, his or her disease, the donor, the stem cell source, the transplant technology, as well as micro- and macroeconomic risk factors (Gratwohl et al. 2015b; Gratwohl et al. 2017). For some patients, early transplant will be the optimal approach; for others, HSCT may need to be delayed. For others, HSCT will never be the preferred option. Obviously, the transplant physician is no longer in a position to adequately assess risk in comparison to the multiple alternative strategies, as it was possible in the old times of the simple EBMT risk score. Machine-learning algorithms will replace risk assessment; the competent physician will still be needed to discuss the results with his or her patients and their families and to conduct the transplant (Verghese et al. 2018). 
Hence, prediction number two: The WHO guiding principles for cell, organ, and tissue transplants, "data collection and data analysis are integral parts of the therapy", need to become a mandatory reality for all transplant teams (WHO 2010). The gap between transplant numbers and reports (Fig. 2.1) has to be closed. Reporting has to become real-time and life-long. The EBMT and transplant centers have to adapt. Data and quality management will become a "condition sine qua non" for all, with close interactions between local, national, and international organizations. Machine learning will end the individualistic center unique transplant techniques. It will no longer be possible to apply hundreds of different GvHD prevention methods and a multitude of conditioning regimens, just by the argument "I have good experience with my method." Standardization will permit correct personalized medicine, as outlined above. Obviously, assessment of outcome can no longer be restricted to transplanted patients; it will need the correct comparison with non-transplant strategies on a routine basis.

Hence, prediction number three: HSCT centers and the EBMT will no longer be isolated in the treatment landscape. HSCT will need to be integrated into the treatment chain, from diagnosis to early treatment, transplant decisions, and secondary treatment, up to life-long follow-up. Not all of these steps have to occur at the transplant center, but they need to be coordinated by the expert team. Data have clearly shown that transplant experience, as measured in patient numbers and years, is associated with outcome (Gratwohl et al. 2015b). No center will have sufficient expertise for all diseases amenable to HSCT or for all transplant techniques, e.g., bone marrow harvest. HSCT centers will have to decide on their priorities, jointly with their referral and their after-care chain, within their city, their country, or with neighboring countries for coordination.

Hence, final prediction: EBMT can take the science-based lead for coordination and standardization, guide in reorganization of networks with non-transplant treatment chains, and priori- tize comparative studies, independent of pressure groups. Then, history will tell, whether the proverb from a contemporary of von Humboldt, Georg Wilhelm Friedrich Hegel (1770-1831) "History teaches us that man learns nothing from history." (Spier 2015), can be overcome. The potential is here.

\section{References}

11th annual meeting of the EBMT (European Cooperative Group for Bone Marrow Transplantation). Bad Hofgastein (Salzburg). Austria, January 28-30, 1985. Exp Hematol. 1985;13(Suppl 17):1-154.

Bortin MM. A compendium of reported human bone marrow transplants. Transplantation. 1970;9:571-87.

Copelan EA. Hematopoietic stem cell transplantation. N Engl J Med. 2006;354:1813-26.

Crowther D, Bateman CJ, Vartan CP, et al. Combination chemotherapy using L-asparaginase, daunorubicin, and cytosine arabinoside in adults with acute myelogenous leukaemia. Br Med J. 1970;4(5734):513-7.

Ford CE, Hamerton JL, Barnes DW, Loutit JF. Cytological identification of radiation-chimaeras. Nature. 1956;177:452-4.

Gratwohl A, Pasquini MC, Aljurf M, Worldwide Network for Blood and Marrow Transplantation (WBMT), et al. One million haemopoietic stem-cell transplants: a retrospective observational study. Lancet Haematol. 2015a;2:e91-100.

Gratwohl A, Schwendener A, Baldomero $\mathrm{H}$, et al. Changes in the use of hematopoietic stem cell transplantation: a model for diffusion of medical technology. Haematologica. 2010;95:637-43.

Gratwohl A, Sureda A, Baldomero H, Joint Accreditation Committee (JACIE) of the International Society for Cellular Therapy (ISCT), the European Society for Blood and Marrow Transplantation (EBMT), the European Leukemia Net (ELN), et al. Economics and outcome after hematopoietic stem cell transplantation: a retrospective cohort study. EBioMedicine. 2015b;2:2101-9.

Gratwohl A, Sureda A, Cornelissen J, et al. Alloreactivity: the Janus-face of hematopoietic stem cell transplantation. Leukemia. 2017;31:1752-9.

Hochhaus A, Larson RA, Guilhot F, et al. IRIS investigators. Long-term outcomes of Imatinib treatment for chronic myeloid leukemia. N Engl J Med. 2017;376:917-27.

Jacobson LO, Marks EK, Gaston EO, Robson M, Zirkle RE. The role of the spleen in radiation injury. Proc Soc Exp Biol Med. 1949;70:740-2.

Kay HE, Powles RL, Sloane JP, Farthing MG. Cyclosporin A in human bone marrow grafts. Haematol Blood Transfus. 1980;25:255-60. 
Le DT, Uram JN, Wang H, et al. PD-1 blockade in tumors with mismatch-repair deficiency. $\mathrm{N}$ Engl J Med. 2015;372:2509-20.

Lorenz E, Uphoff D, Reid TR, Shelton E. Modification of irradiation injury in mice and Guinea pigs by bone marrow injections. J Natl Cancer Inst. 1951;12:197-201.

Mathé G, Jammet H, Pendic B, et al. Transfusions and grafts of homologous bone marrow in humans after accidental high dosage irradiation. Rev Fr Etud Clin Biol. 1959;4:226-38.

McCann SR. A history of haematology. From herodotus to HIV. Oxford medical histories. London: Oxford University Press; 2016.

Osgood EE, Riddle MC, Mathews TJ. Aplastic anemia treated with daily transfusions and intravenous marrow; a case report. Ann Intern Med. 1939;13:357-67.

Schinck P. Ernst Neumann als Begründer der Hämatologie. Dissertation Königsberg; 1920.

Speck B, Gluckman E, Haak HL, van Rood JJ. Treatment of aplastic anaemia by antilymphocyte globulin with and without allogeneic bone-marrow infusions. Lancet. 1977;2(8049):1145-8.

Spier F, editor. Big history and the future of humanity. Chichester: Wiley; 2015.
The bone-marrow. JAMA. 1908;LI(23):1997. https://doi. org/10.1001/jama.1908.02540230083025.

Thomas ED. A history of allogeneic hematopoietic cell transplantation. In: Appelbaum FR, Forman SJ, Negrin RS, Blume KG, editors. Thomas' hematopoietic cell transplantation. Chichester: Wiley; 2007. p. 3-7.

Thomas ED, Lochte HL Jr, Lu WC, Ferrebee JW. Intravenous infusion of bone marrow in patients receiving radiation and chemotherapy. $\mathrm{N}$ Engl $\mathrm{J}$ Med. 1957;257:491-6.

Thomas ED, Storb R, Clift RA, et al. Bone-marrow transplantation (second of two parts). N Engl J Med. 1975;292:895-902.

Tran E, Longo DL, Urba WJ. A milestone for CAR T cells. N Engl J Med. 2017;377:2593-6.

Van Bekkum DW, De Vries MJ. Radiation chimeras. New York: Academic Press; 1967.

Verghese A, Shah NH, Harrington RA. What this computer needs is a physician humanism and artificial intelligence. JAMA. 2018;319:19-20.

World Health Organization. WHO guiding principles on human cell, tissue and organ transplantation. Transplantation. 2010;90:229-33.

Open Access This chapter is licensed under the terms of the Creative Commons Attribution 4.0 International License (http://creativecommons.org/licenses/by/4.0/), which permits use, sharing, adaptation, distribution and reproduction in any medium or format, as long as you give appropriate credit to the original author(s) and the source, provide a link to the Creative Commons license and indicate if changes were made.

The images or other third party material in this chapter are included in the chapter's Creative Commons license, unless indicated otherwise in a credit line to the material. If material is not included in the chapter's Creative Commons license and your intended use is not permitted by statutory regulation or exceeds the permitted use, you will need to obtain permission directly from the copyright holder. 